\title{
ORGANIC AND BIO-FUNGICIDE APPLICATION ON THE GROWTH AND YIELD RESPONSE OF ONION (ALLIUM CEPA L)
}

\author{
ADIZA V. DELA CRUZ \\ Assistant Professor College of Agriculture, Nueva Ecija University of Science and Technology - Gabaldon Campus, Gabaldon, \\ Nueva Ecija, Philippines
}

\begin{abstract}
Modern farming affects our world, by land exhaustion, soil erosion, and soil compaction, loss of cultivated biodiversity, habitat destruction, contaminated food and destruction of traditional knowledge. The study was aimed to determine the effects of organic fertilizers and bio-fungicide (Trichoderma sp.) on the growth and yield of onion. It was conducted at Nueva Ecija University of Science and Technology - Gabaldon Campus Research Area, Gabaldon Nueva Ecija. Organic fertilizers performed well in all data gathered: crop stands, Disease Incidence, Diseases Severity, Size of the Bulbs, Height of the Leaves, Yield/ha (Marketable and Non-Marketable), and in profit. And among the two organic fertilizers, Titan fertilizer applied with 20 grams of bio-fungicide gave the lowest disease incidence and diseases severity in onion and Titan with combination of 15 grams of bio-fungicide gave the highest mean in size of the bulb (10.27). On the other hand, Exceed Fertilizer with the combination of 15 grams Bio-fungicide gave the highest means in terms of crop stands (4.66), height of leaves $(36.49 \mathrm{~cm})$, Total Yield $(2,337.50 \mathrm{~kg} / \mathrm{ha})$ and marketable yield of 2,225.0 kg/ha. Results reveal that Exceed Organic fertilizer with combination of 15 grams of bio-fungicide makes the crops good with higher leaves that produce a marketable and better yield.
\end{abstract}

KEYWORDS: Onion, Organic Fertilizer, Bio-Fungicide, Trichoderma, Growth \& Yield

Received: Mar 05, 2021; Accepted: Mar 25, 2021; Published: Jun 09, 2021; Paper Id.: IJMPERDAUG20212

\section{INTRODUCTION}

Onion (Allium cepa L.) is a popular crop grown for its pungent bulbs and flavorful leaves. It is widely grown throughout the world. The bulb is composed of concentric, fleshy, enlarged leaf bases or scales. In the Philippines, onion is known in the local dialect as "sibuyas" and considered one of the most important bulb crops. The most commonly grown species of alliums in the Philippines are Allium cepa L. (onion), A. sativum L. (garlic), and A. ascalonicum L. (shallot). These species are widely used as spices and are common ingredients of most Filipino dishes. About $78 \%$ of the total production of garlic and onion is used in food preparation (Lopez and Anit, 2008). It is planted after rice in Central Luzon during the months of November to April. It took about two decades for onion to become a major cash crop. In recent years, the area devoted to its cultivation has expanded considerably (Villalon, 2004).

A total of 6,454 hectares in Nueva Ecija had been planted with onion and it ranks as third among vegetables planted in terms of area of production, fifth in both quantity and returns, and considered as one of the country's top foreign exchange earners (Reyes, 2005). Bongabon which is considered the leading municipality in terms of area planted with onion, Red Creole was about 1,623 hectares were being used for onion production. In Gabaldon, Nueva Ecija alone, farmers devoted 408 hectares to onion production (Reyes, 2005). 
However, in spite of the increase in areas planted, maximum production has not been attained. This is maybe due to the proliferation of insect pests and diseases that continue to strain onion in almost all production areas in the country. Onion is commonly attacked by pathogenic organisms especially fungi which impede its growth and yield performance. Farmers often apply synthetic pesticides to the plants which cost very high nowadays (Reyes, 2005).

Another factor to be considered in the success of growing onion is the sources and amounts of fertilizer to be used. Unbalanced fertilizer can provoke a more virulent attack of disease or pest. This may be the result of either plants undernourishment or an oversupply of nutrients. Excessive nitrogen may increase insect infestation and weak plants show less resistance to plant diseases (Schwab et.al., 1995). Excessive use of chemical fertilizer and pesticides has often adversely affected the environment and created many problems on food safety and quality, as well as on human and animal health. Consequently, there has been growing interest in nature farming and organic agriculture by consumers and environmentalists as a possible alternative to chemical, conventional agriculture. Moreover, careless use of fertilizer and other chemicals (pesticides and herbicides, etc.) in intensive agriculture resulted to increasing ecological and environmental problems (Panda, 2006).

According to Higa and Parr (1994) soil is a complex system where processes have direct influence on crop nutrition and plant health. Crop growth and development are closely related to the nature of the soil microflora. They added that beneficial soil microorganisms will increase naturally when organic amendments are applied to the soil as carbon, energy and nutrient sources. These soil microorganisms also induce normal plant development and resistance to the attack of soil-borne plant pathogens. In this study, Trichoderms spp. was used as bio-fungicide and organic fertilizer as an alternative nutrient source for onion. The growth and yield performance of onion were determined as well as the disease incidence and disease severity was monitored and recorded. The mineral content of the soil was analyzed to investigate its effect on the chemical property of the soil specifically the N, P, and K of the soil before and after the conduct of the study.

\section{METHODS AND MATERIALS}

\section{Experimental Design}

A 3x4 factorial experiment in Randomized Complete Block Design (RCBD) with four replications was used in the experiment. The fertilizers (organic and inorganic) were designated as the main treatments with three levels and the biofungicide as sub-treatments with four levels. All treatment combinations were assigned at random for each four replication. The plots measured $1 \mathrm{~m} \times 1 \mathrm{~m}$. The distance between block is 0.5 meter and 0.5 per treatments/plot. The planting distance is $8 \mathrm{~cm}$ between rows and $10 \mathrm{~cm}$ between hills in a row having a size of 1 sq. meter/plot. Red Creole onion variety was used in the study. One can of onion seeds (400 grams) was acquired and divided into 12 parts for treatments using a digital weighing scale. Ten plant samples were assigned at the middle portion of the plot and were selected randomly through draw lots. The two rows and two hills on both sides were disregarded to avoid edge effect. Sample plants were marked by stick with appropriate numbers.

\section{Biofungicide Preparation and Application}

Trichoderma gathered at PhilRice, Maligaya, Science City of Muñoz, Nueva Ecija, were mixed and applied at 0,10,15,20 grams of corn grits for every 16 liters of water. The spores in the inoculated corn grits were dislodged. The seedbed was applied with forty $\mathrm{ml}$ biofungicides solution before sowing of the seeds. Whereas, for the experimental plot, $16 \mathrm{ml}$ of the biofungicides solution was applied before transplanting. 


\section{Soil Analysis}

Soil Analysis before and after the conduct of the study was determined s OM, N. P, and K of the soil. Prior to land preparation, soil sample were gathered randomly in the field and subjected to analysis. For analysis of the soil Kjeldhal Method was used for Nitrogen $(\mathrm{N})$ content determination of the soil under study and Flame Photometer Method for Phosphorus (P) and Potassium (K).

\section{Cultural Management}

The seedbeds were laid parallel to each other with $30 \mathrm{~cm}$ distance having a size of $50 \mathrm{~cm}$ x 5 meters. The seedbeds were raised $10 \mathrm{~cm}$ high. Once the soil was pulverized, the organic fertilizers were mixed thoroughly before the leveling of the surface. Organic fertilizers were composed of 5 kilograms/plot of Titan Organic fertilizer and 7.5 kilograms/plot of Exceed Organic Fertilizer. The seeds were divided into 12 parts and broadcasted evenly per plot. To eliminate the falling of seeds to the side ground due to strong winds, these were pressed by rolling a banana trunk and were covered well with rice hull. The seedlings were watered thoroughly every morning and afternoon for the first 20 days. Saturating the soil in the afternoon was avoided. After 20 days, watering was done only in the morning. For inorganic treatment, starter solutions were applied three weeks after the emergence of the seeds. Said inorganic treatment was composed of dissolved 50 grams of urea in one kerosene can of water. One solution was good for two seedbeds. Forty-five day-old onion seedlings were pulled, soaked in bio-fungicides and transplanted in $1 \mathrm{~m}$ x $1 \mathrm{~m}$ plots at a distance of $8 \mathrm{~cm}$ between hills and $10 \mathrm{~cm}$ between rows with a total number of 108 seedlings per plot. The seedlings under treatment were soaked in Trichoderma sp. The 10 grams spores of inoculated corn grits were dislodged and mix in 16 liter water. A liter of the solution was placed in a basin and the seedlings were soaked for 15 minutes before transplanting (Philrice, 2011). In transplanting, wooden or bamboo dibbles were used to make a shallow hole, and then the seedlings were inserted up to the root plate. Initial irrigation was applied immediately after transplanting. Gravitational irrigation was applied after transplanting. Subsequent irrigation was based on the soil moisture content. Crop stand which describes the overall crop stand per plot was taken two weeks after transplanting and monthly thereafter. Crop stand assessment was based on the vegetative stage of the crop using the scale adopted from the study of Villalon, 2004.

\section{Rating Scale on Crop Stand of Onion}

The following are rating scale on crop stand of onion.

\begin{tabular}{|c|l|l|}
\hline Scale & \multicolumn{1}{|c|}{ Ratings } & \multicolumn{1}{c|}{ Description } \\
\hline 1 & $\begin{array}{l}\text { Excellent, extra } \\
\text { vigorous }\end{array}$ & $\begin{array}{l}\text { Leaves are dark green in } \\
\text { color, robust and tall }\end{array}$ \\
\hline 3 & Good, vigorous & $\begin{array}{l}\text { Leaves green in color, } \\
\text { slightly robust and tall }\end{array}$ \\
\hline 5 & Fair, Normal & $\begin{array}{l}\text { Leaves are pale and } \\
\text { stunted }\end{array}$ \\
\hline 7 & Poor, Weak & $\begin{array}{l}\text { Leaves are pale, twisted } \\
\text { and stunted }\end{array}$ \\
\hline 9 & $\begin{array}{l}\text { Unacceptable, very } \\
\text { weak }\end{array}$ & $\begin{array}{l}\text { Leaves are twisted and } \\
\text { wilted }\end{array}$ \\
\hline
\end{tabular}

\section{Disease Incidence}

Disease incidence was calculated by getting the proportion of plants examined. It was evaluated two weeks after 
transplanting and monthly thereafter. To get the percentage of disease incidence, (the formula was adopted from the study of Villalon, 2004).

No. of Infected plants per plot

Percent Disease Incidence = $\mathrm{x} 100$

Total no. of plants per plot

The disease severity of the plant was visually estimated. The percentage of the target area or plant part covered by symptoms was recorded, and the percentage of disease severity was calculated by averaging the disease severity of all plants including those scores $=0$. Disease severity was calculated using the hereunder formula: (the formula was adopted from the study of Villalon, 2004).

(0) $n+(1) n+\ldots .+(9) n$

Percent Disease Severity = x 100

$\mathrm{N} \times 9$

Where:

$\mathrm{n}=$ number of infected plants classified by grade

$\mathrm{N}=$ Total number of samples

The scale used for disease assessment is adopted from IRRI's Standard Evaluation System for Rice as follows:

\begin{tabular}{|c|c|}
\hline Scale & Leaf Area Affected \\
\hline 0 & $0 \%$ \\
\hline 1 & $1-5 \%$ \\
\hline 3 & $6-12 \%$ \\
\hline 5 & $13-25 \%$ \\
\hline 7 & $26 \%-50 \%$ \\
\hline 9 & $-100 \%$ \\
\hline
\end{tabular}

\section{Soil Analysis}

Applications of inorganic fertilizers were dependent upon the result of the soil analysis on the requirement and on the recommended rate for the onion. Basal application was done immediately prior to the leveling operation of the field to effect thorough incorporation into the soil. It was applied with urea (45-0-0), (16-20-0) and complete fertilizer (14-14-14) in the rate of 2 grams, 5 grams and 22 grams per plot, respectively. The second application was on the banking time/bulb formation. Ten grams per plot of urea was applied 56 days after transplanting (DAT). For organic fertilizer, the treatments were applied based on the manufacturer's recommendation. Two kilograms of Titan organic fertilizer per plot and three kilograms of Exceed organic fertilizer per plot were applied two days before transplanting.

\section{Weed Control}

Weeding was done throughout the seedling and the production period depended on the density population of the weeds. 


\section{Harvesting}

Crops were harvested when at least $50 \%$ of the leaves of the plants started to topple down. The climatic condition was also considered in harvesting the crops.

\section{Statistical Analysis}

Data gathered was analyzed using Analysis of Variance (ANOVA). The Duncan Multiple Range Test (DMRT) was applied at 0.5 and 0.1 probability levels to compare treatment means.

\section{RESULTS AND DISCUSSIONS}

\section{Growth of Onion}

Table 1 presents the crop performances at 1st, 2nd and 3rd observations were significantly affected by the sources of fertilizer. At 1st observation, M3 (Titan organic fertilizer) applied with 0, 10 and 15 grams of bio-fungicides, gave a good, vigorous crop stand while M3S4 (Titan organic fertilizer + 20 grams of bio-fungicides) resulted in a fair, normal crop stand. The same results were observed on treatments under M2 (Exceed organic fertilizer) applied with 0, 10, 15 and 20 grams of bio-fungicides. The effect of organic fertilizer on the crop stand of onion was significant during the second observation and highly significant during the third observation. However, the interaction of fertilizer sources to different amounts of bio-fungicide applied was not significant. The use of organic fertilizer significantly favored a good crop stand of onion. The effect of the two organic fertilizers, M2 (Exceed organic fertilizer) and M3 (Titan organic fertilizer) were comparable. But when compared based on the rate of bio-fungicides applied, M2 (Exceed organic fertilizer) was found to have better effects.

Crop stand of onion applied with inorganic fertilizer was poor and weak at 1st observation (2 WAT) up to the second observation (6 WAT). However, the onion plants were able to recover during the 3rd observation after the 2nd application of inorganic fertilizer which was at banking time. The poor crop stand can be attributed to the insufficient supply of nutrients needed by the plants when applied with inorganic fertilizer. This finding is supported by the study of Garcia (2005) confirmed that organically and chemically fertilized crops may differ in leaf nitrogen, vitamins, amino acids and other nutrients which are significant factors that may account for the nutrition of the plans resulting in vigorous growth.

\section{Height of Onion at Harvest}

Treatments applied with organic fertilizer (Titan and Exceed) obtained the highest means in terms of height although did not show a significant difference at 5\% level at DMRT. While onion applied with inorganic fertilizers showed a poor response in terms of height (Table 1). Inoculation of bio-fungicide responses was attained in treatments applied with organic fertilizers. The highest onion was recorded in M2 (Exceed Organic Fertilizer) applied with 15 grams of biofungicide. Interactions between the applications of organic fertilizers and bio-fungicides were not significantly different in terms of the height of onion.

\section{Size of Onion Bulbs}

Inorganically fertilized onion (M1) obtained the smallest bulb due to its sluggish and poor growth; whereas the biggest onion bulbs were recorded in M3S3 (Titan organic fertilizer + applied with 15 grams of bio-fungicides) with a mean of 10.27 , followed by M2S3 with a mean of 10.19 , M3S4 with a mean of 10.18 , and M3S2 with a mean of 10.05 . It is also 
attributed by the lowest disease incidence and disease severity to the treatments applied with biofungicide, thus resulting in better bulb sizes (Table 1).

\section{Yield of Onion}

Table 2 presents the data on the weight of the onion bulbs produced per treatment as affected by different fertilizer and biofungicide applications. Results revealed that onion applied with organic fertilizer obtained the highest means. Yield of onions from inorganically fertilized treatment was lower.

The result was further supported by the study of Yoldas (2011) where he stressed that the application of organic manures activates many species of living organisms that release phytohormones and may stimulate plant growth and improve the absorption of nutrients. Increase in the yield of onion is evident when organic fertilizers are applied in onion.

The table further showed that the highest yield in weight of onions was recorded in M2S3 (Exceed organic fertilizer applied with 15 grams bio-fungicide) with a mean of 2,524.5 grams per square meter followed by M3S4 (Titan organic fertilizer applied with 20 grams of bio-fungicides) with a mean 2,308.5 grams per square meter. Onion applied with the two kinds of organic fertilizers with varying amounts of bio-fungicides showed no significant difference. However, significant differences were noted between onions applied with organic fertilizer and with inorganic fertilizer in terms of yield in weight.

Between the two organic fertilizers used in the study, onion applied with Exceed organic fertilizers recorded the highest yield. This finding validated the claim of Titan manufacturers that Titan was a natural organic fertilizer while Exceed fell into the category of a fortified organic fertilizer. Mamaril (2004) explained that plants do not directly use the nutrients found in organic materials and the amounts of essential plant nutrients are very low. To supply the amount of nutrients required by the plants, a tremendous volume of organic materials is required. Consequently, the remedy is to apply the micronutrients of organic fertilizer in inorganic forms, which is likely that such material has been fortified with inorganic fertilizer.

\section{Marketable and Non Marketable Yield of Onion (kg/ha)}

Figure 1 presents the comparable results of marketable yield to nonmarketable yield in onion. M2S3 (Exceed organic fertilizer applied with 15 grams of bio-fungicides) obtained the highest marketable yield of onion and the highest nonmarketable yield in onion was obtained by M1S1 and M1S2 (Inorganic fertilizer with 0 and 10 grams of biofungicides). The results showed that Factor A (fertilizer sources) significantly affected the yield of onion. However, the findings revealed that interaction between Factor A (fertilizers source) and Factor B (bio-fungicides) were not significantly different in all experimental units.

\section{Percent Disease Incidence}

Figure 2 shows the disease incidence of onion as affected by fertilizer and bio-fungicide applications. Highest disease incidence was observed during the 2nd observation, i.e., 6 weeks after transplanting. It was highly observed in plots applied with inorganic fertilizer with 10 grams of bio-fungicide. M3S4 (Titan Organic fertilizer with 20 grams biofungicide) had the lowest percentage of disease incidence compared to the other treatment applied with Exceed organic fertilizer (M2). 
The results confirmed Lampkin's (1990) findings where he stated that organic amendments had the ability to stimulate the complexity of the predatory microbes, thus help to keep potential pests and pathogens under control. He further stressed that in some soils the high level of organic matter and higher biological activity are directly associated with low levels of disease incidence, even when pathogen was introduced in the presence of a susceptible host. Agriculture Magazine (2004) also stated that mycorrhizal fungi, which naturally occurring in soil, are soil beneficial organisms. It reported that these organisms have been helping farmers for thousands of years by improving water uptake and in achieving efficient use of nutrients and suppressing diseases. Applying certain chemicals to the soil has likely inhibited the growth of these beneficial fungi. Thus, high disease incidences are likely to occur.

\section{Percent Disease Severity}

Figure 3 is the effect of fertilizer and biofungicides application on the percentage of disease severity in onion on 3 consecutive observations was shown in Figure 4. Data showed that the lowest percentage of diseases severity was obtained by M3S4 (Titan organic fertilizer applied with 20 grams Biofungicide). Rapid increase in disease severity was observed in M2 (Exceed Organic Fertilizer) at 3rd observation. Onion plants applied with Exceed fertilizer at first block were attacked by insects that served as avenue for the pathogen to infect the crops. The experimental units were applied with organic pesticide (Sili + Lemon grass extract). Whereas, onions applied with inorganic fertilizers were infected severely by diseases because of its poor growth and poor crop stand which were very susceptible to disease infection. Allison (1973), as cited by Garcia (2005), claimed that insects and plant diseases are not serious menace to crop production only if all chemicals are excluded from farming operations and natural methods are to be used.

Table 1. Growth and Yield of Onion as Influenced by the Application of Organic and Bio-Fungicide in Terms of Crop Stand, Height, Size and Yield

\begin{tabular}{|c|c|c|c|c|c|c|c|}
\hline \multirow{2}{*}{\multicolumn{2}{|c|}{ Treatment }} & \multirow{2}{*}{\multicolumn{3}{|c|}{ Crop Stand }} & \multirow{4}{*}{$\begin{array}{c}\begin{array}{c}\text { Onion } \\
\text { Height at } \\
\text { Harvest }\end{array} \\
27.14^{\text {cd }} \\
\end{array}$} & \multirow{3}{*}{$\begin{array}{c}\text { Onion Size } \\
\text { at Harvest }\end{array}$} & \multirow{3}{*}{$\begin{array}{c}\text { Yield } \\
945^{\mathrm{c}}\end{array}$} \\
\hline & & & & & & & \\
\hline \multirow{4}{*}{ M1 } & $\mathrm{S} 1$ & $\frac{2 \text { WAT }}{6.55^{\mathrm{a}}}$ & $\frac{\text { 6 WAT }}{5.90^{\mathrm{abc}}}$ & $\frac{10 \text { WAT }}{5.90^{\mathrm{abc}}}$ & & & \\
\hline & S2 & $635^{\mathrm{ab}}$ & $60^{\mathrm{abc}}$ & $60^{\mathrm{abc}}$ & & $741^{\mathrm{b}}$ & $10665^{\mathrm{c}}$ \\
\hline & S3 & $6.48^{a}$ & $6.70^{\mathrm{a}}$ & $6.70^{\mathrm{a}}$ & $28.08^{\mathrm{bcd}}$ & $6.72^{b}$ & $985.5^{\mathrm{c}}$ \\
\hline & $\mathrm{S} 4$ & $6.20^{\mathrm{ab}}$ & $6.18^{\mathrm{abc}}$ & $6.18^{\mathrm{abc}}$ & $26.75^{\mathrm{cd}}$ & $8.28^{\mathrm{ab}}$ & $1,255.5^{\mathrm{bc}}$ \\
\hline \multirow{4}{*}{ M2 } & S1 & $4.40^{\mathrm{cd}}$ & $5.70^{\mathrm{abc}}$ & $5.70^{\mathrm{abc}}$ & $35.72^{\mathrm{a}}$ & $9.60^{\mathrm{a}}$ & $2,052^{\mathrm{ab}}$ \\
\hline & $\mathrm{S} 2$ & $4.75^{\mathrm{cd}}$ & $6.40^{\mathrm{ab}}$ & $6.40^{\mathrm{ab}}$ & $33.70^{\mathrm{a}}$ & $9.90^{\mathrm{a}}$ & $1,782^{\mathrm{abc}}$ \\
\hline & S3 & $4.33^{\mathrm{cd}}$ & $4.66^{\mathrm{c}}$ & $4.66^{c}$ & $36.49^{\mathrm{a}}$ & $10.19^{\mathrm{a}}$ & $2,524.5^{\mathrm{a}}$ \\
\hline & $\mathrm{S} 4$ & $5.10^{\mathrm{bc}}$ & $5.90^{\mathrm{abc}}$ & $5.90^{\mathrm{abc}}$ & $31.37^{\mathrm{abc}}$ & $9.61^{\mathrm{a}}$ & $1,606.5^{\mathrm{abc}}$ \\
\hline \multirow{4}{*}{ M3 } & $\mathrm{S} 1$ & $3.70^{\mathrm{d}}$ & $4.73^{\mathrm{bc}}$ & $4.73^{b c}$ & $33.77^{\mathrm{a}}$ & $9.80^{\mathrm{a}}$ & $2,268^{\mathrm{a}}$ \\
\hline & $\mathrm{S} 2$ & $3.70^{\mathrm{d}}$ & $5.03^{\mathrm{abc}}$ & $5.03^{\mathrm{abc}}$ & $35.66^{\mathrm{a}}$ & $10.05^{\mathrm{a}}$ & $2,214^{\mathrm{a}}$ \\
\hline & S3 & $3.85^{\mathrm{cd}}$ & $5.20^{\mathrm{abc}}$ & $5.20^{\mathrm{abc}}$ & $35.95^{\mathrm{a}}$ & $10.27^{\mathrm{a}}$ & $2,106^{\mathrm{ab}}$ \\
\hline & $\mathrm{S} 4$ & $4.14^{\mathrm{cd}}$ & $5.30^{\mathrm{abc}}$ & $5.30^{\mathrm{abc}}$ & $32.94^{\mathrm{ab}}$ & $10.18^{\mathrm{a}}$ & $2,308.5^{\mathrm{a}}$ \\
\hline
\end{tabular}

$(p \leq 0.5)$ 


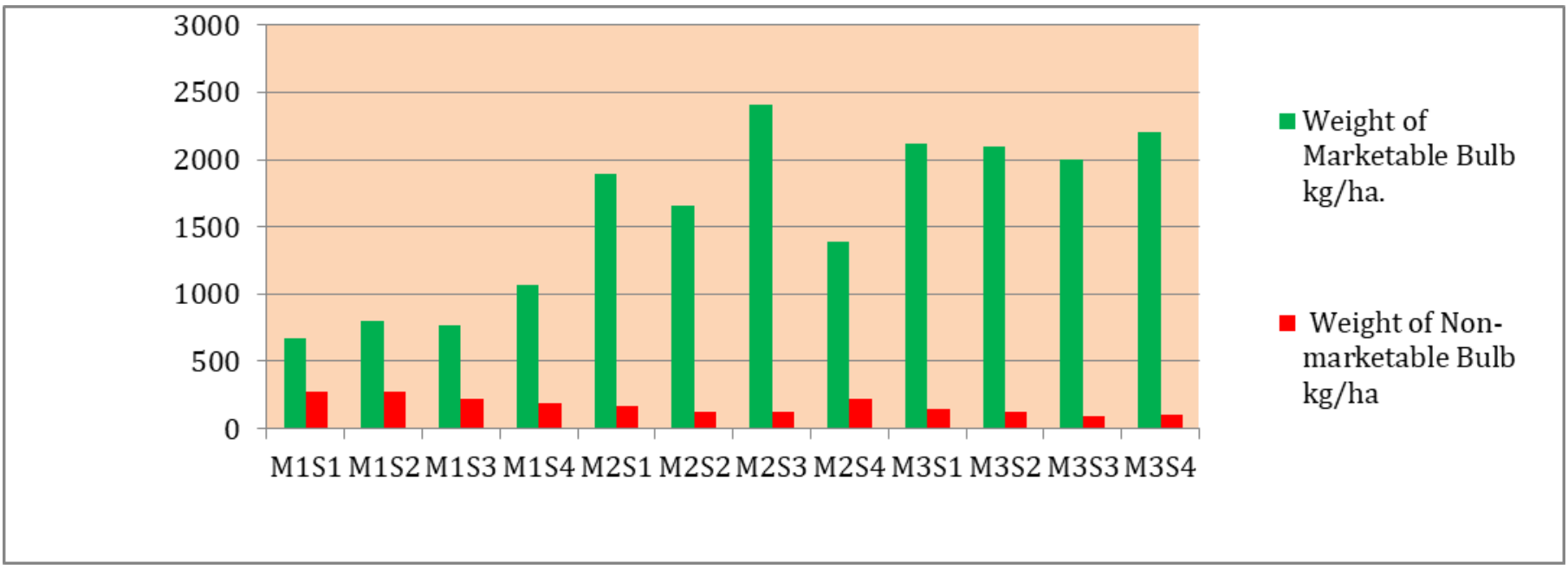

Figure 1: Descriptive Analysis of Organic and Bio-Fungicide Application on the Growth and yield Response of Onion in Terms of Marketable and Non-Marketable Yield of Onion.

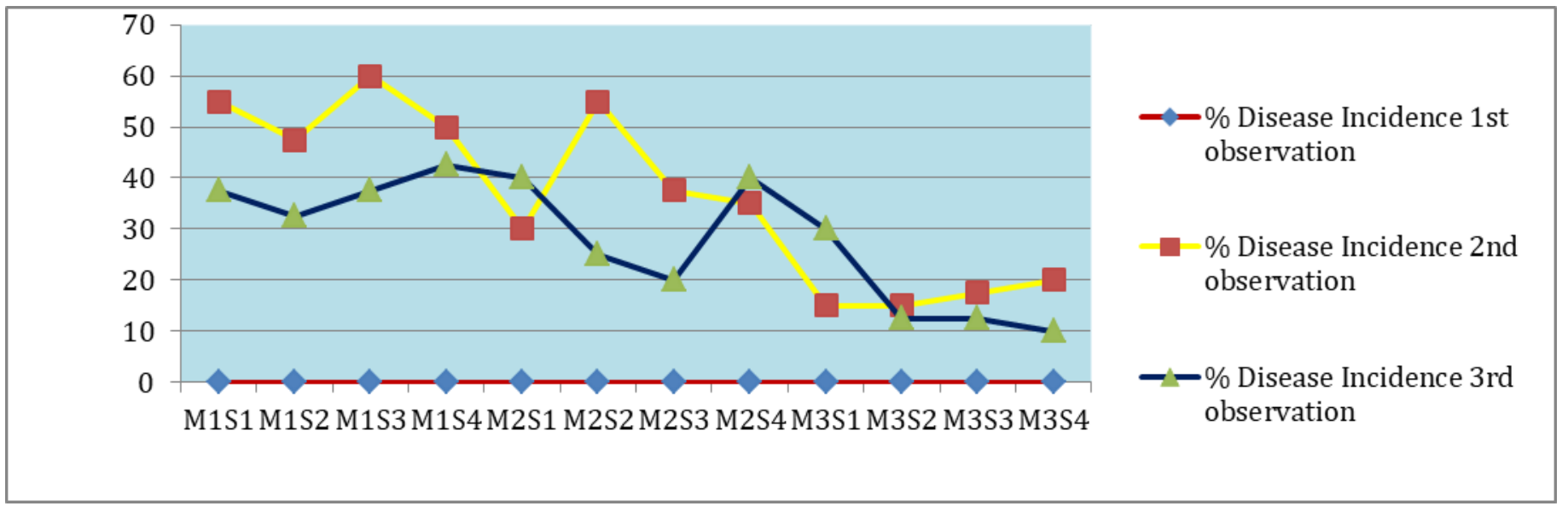

Figure 2: Descriptive Analysis of Organic and Bio-Fungicide Application on the Growth and Yield Response of Onion in Terms of Disease Incidence.

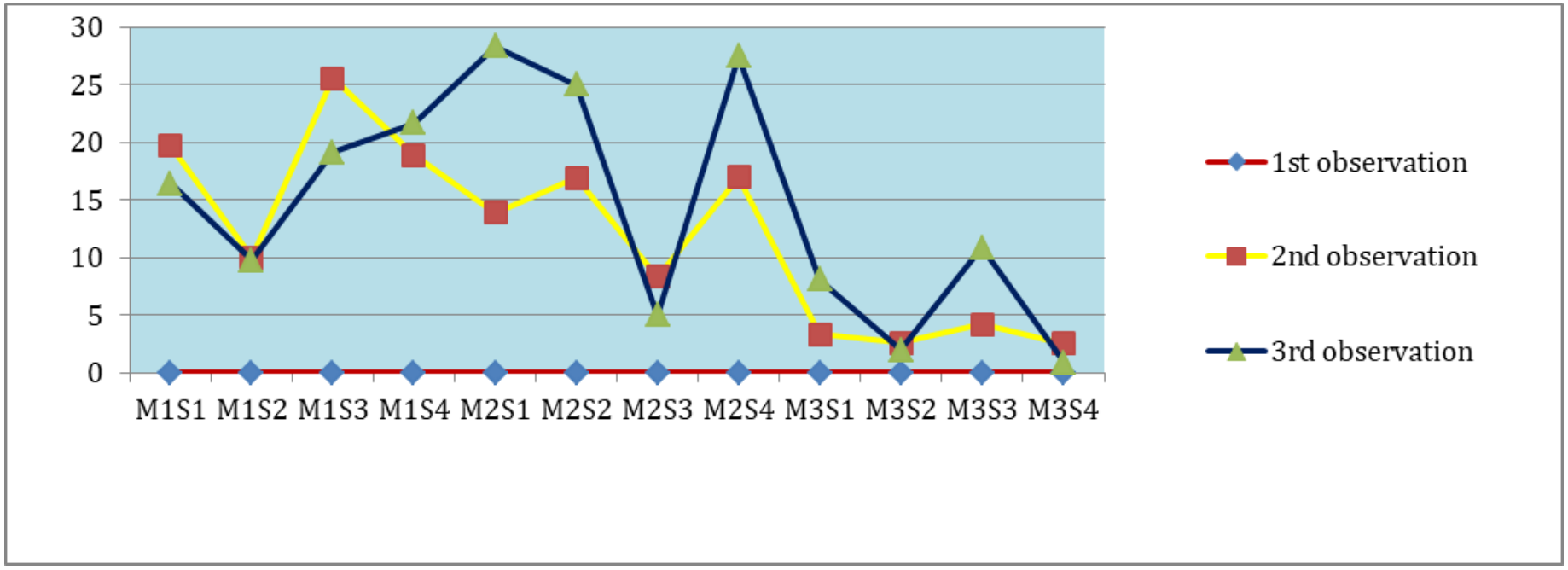

Figure 3: Descriptive Analysis of Organic and Bio-Fungicide Application on the Growth and Yield Response of Onion in Terms of Disease Severity. 


\section{CONCLUSIONS}

Onion applied with organic fertilizer regardless of the amount of biofungicide incorporated produced longer leaves, bigger bulb, and better marketable yield than onion applied with inorganic fertilizer. Organic fertilizer made the onion crops healthier and resistant against insect pests and diseases damage and infestation, while the biofungicide enhanced the soil quality thus preventing disease-causing agents to interfere in the crops system. Inorganic fertilizer made the soil acidic causing inefficient absorption of nutrients by plants; whereas, organic fertilizer improved the Nitrogen, Phosphorus and Potassium contents of the soil.

\section{REFERENCES}

1. Agriculture Magazine. 2004. Vol. VIII NO. 6. P.63

2. Agriculture Magazine. 2011. Vol. XV. No. 2. pp. 10, 16-17

3. Yazachew Genet Ejigu, Pangirayi Bernard Tongoona \& Beatrice Elohor Ifie, "General and Specific Combining Ability Studies of Selected Tropical 383 White Maize Inbred Lines for Yield and Yield Related Traits”,International Journal of Agricultural Science and Research (IJASR), Vol. 7, Issue 2,pp, 381-396

4. Bezdick, D. F. and J. F. Powers. 1984. Organic Farming: Current Technology and its Role in a Sustainable Agriculture. ASA Spec. Publication No. 46 Amer. Soc. Agron.

5. Anuj Kumar, Shailendra Singh Gaurav, Deepak Kumar Bahuguna, Priyanka Sharma, Tejbir Singh \& Pooran Chand, "Analysis of Variability, Heritability and Genetic Advance for Yield and Yield Related Trait in Wheat (Triticum Aestivum L.) Genotypes”, International Journal of Agricultural Science and Research (IJASR), Vol. 7, Issue 4,pp, 583-590

6. Biag, H.M. 2010. Trichoderma: Save on Input Cost with Biofungicide. Agriculture magazine. Vol. XIV. No. 4. Pp. 54-55

7. Briones, T. 1997. Organic Fertilizer. Now they Use It. Now They Don't. Philrice Newsletter. 10 (3)

8. Brotman, et. al., 2006. Plant Biocontrol by Trichoderma spp.Department of Biological Chemistry http://www.weizmann.ac.il/Biological_Chemistry/scientist/Chet/Chet.html

9. Megha Goyal \& Urmil Verma, "Weather Based Wheat Yield Forecasting in Eastern Zone of Haryana”,International Journal of Applied and Natural Sciences (IJANS), Vol. 7, Issue 4,pp; 19-22

10. Bulb Onion Production Guide. 2000. PCARRD Information Bulletin No 197/2000 Department of Agriculture http://www.darfu4b.da.gov.ph/onion.html

11. Cuevas, V. C. 2006. Soil Inoculation with Trichoderma speudiningu Rifai Enhances Yield of Rice. UPLB. Phil. Journal of Science. 135 (1): 31-37 pp.

12. Sanjeev, U. Verma \& M. Tonk, "Time-Series Modelling for Sugarcane Yield Estimation in Haryana”,International Journal of Applied Mathematics \& Statistical Sciences (IJAMSS),Vol. 4, Issue 6,pp, 53-62

13. Dela Cruz, R. T. 2011. Sweet Sorghum Residue Good Bio-Organic Fertilizer. Agriculture Magazine. $52-53$ pp.

14. Dela Cruz, R. T. 2003. BAR Promotes Organic Agriculture as "Farming with Conscience”. Bureau of Agricultural Research. Web.master@ba.gov.ph

15. Garcia, V. 2005. Managing Striped Flea Beetle, Phyllotreta striolata Fab. By Mulching and Organic Fertilizer on Pechay (Brassica chinensis Linn.)

16. Gay, L.R. Educational Research. 1976. Columbus, Ohio, Charles E. Merill Publishing Company 
17. Gregon, E. B. and G. B. Amar. 2011. Field Evaluation of Antica fr Management of Rice Bacterial Leaf Blight and Tungro. Agriculture magazine. Vol. 15, No. 3. 57 p.

18. Higa, T and Parr, J. F. 1994. Beneficial and Effective Microorganisms for a Sustainable Agriculture and Environment. International nature farming Research center. Atami Japan. www. Agriton, nl/hga.html

19. Kaunlarana Magazine. 2012. $2^{\text {nd }}$ Edition.P.64

20. Lampkin, N. 1990. Pest and Diseases Control. Organic Farming Farmers Press book. pp.214-215

21. Lopez E.L. and E.A. Anit. 2008. Allium Production in the Philippines. http://www.actahort.org/members/showpdf?booknrarnr=358_8

22. Mamaril, C.P., 2004. Agriculture Magazine. Vol. VIII. No. 6. P.12

23. Mohan et. al., Pest and Disease Management in Organic System. agritect.tnau.ac.in/org_farm/IPM\%20 Booklet \% 20for\%20OF-Dr.P.D.pdf)

24. http://www.csrees.usda.gov/nea/ag_systems/in_focus/sustain_ag_if_organic.html

25. National Institute and Food Agriculture. 2009. Sustainable Agriculture and Organic farming.

26. Navarro, M. 2000. Small Organisms Doing Big Job in Agriculture. Agriculture Magazine. Volume15.No. 5.9 p.

27. Panda, S. C. 2006. Soil management and Organic Farming. Agrobios India.

28. Philrice. 2009. Organic Fertilizers. Series. 29. P.1

29. Philrice Magazine. 2011. Vol.24. No. 4

30. Prasad,. 2006. Dictionary for Agriculture

31. Rehka, M. et.al., 2010. The Biological Control of paddy Disease Brown Spot (Bipolaris oryzae) by using Trichoderma viridae in vitro condition. Journal of Biopesticides 3(1 Special Issue) 093-095. 5p.

32. Reyes, G. D. 2005. Chemical Control of Anthracnose (Colletotrichum gloeosporioides (Penzig) Penzig and Sacc.) of Onion. 4 $p$.

33. Robbins, J. 2011. At Organic Farms, Pest Control with Plants. Agriculture Magazine. p. 59

34. Sevilla, C. G. et. al.,1997. Research Methods. Revised Edition. Rex Bookstore Printing Company. 116 p.

35. Schwab, A. et. al., 1995. Pesticides in Tropical Agriculture. Hazards and Alternatives. Bohler Verlag Wurzburg, Germany.

36. Samonte, P. 2011. High Prices Make Bongabon Onion Farmers Instant Millionaires. Agriculture magazine. Volume 15. p.45

37. Samonte, P. 2009. Farmers Increases Productivity by Going Organic. Agriculture Magazine.

38. Sangatanan, P. P. and J. D. Dagoon. 1987. Natural Way of Controlling Pest and Diseases. Organic Farming. Journal: Organic Farmers Association of Iloilo (OFIA). 3 (1) 4

39. Sarian, Z. B. 2011. One bigger Idea that keeps on Spreading. Agriculture Magazine. Volume15, No. 3. 38 p.

40. Sarian, Z. B. 2009. The Pilot is an Organic Farmer. Agriculture Magazine. pp.52-53.

41. TsingHua. Use of Trichoderma spp. on soil microbiology improvement for organic agriculture in Costa Rica. Journal of Zhejiang University(Agric.\& Life Sci.) http://www.shvoong.com/social-sciences/1605058-trichoderma-spp-soil-microbiologyimprovement/ 
42. Villalon, A. V. 2005. Effect of Nitrogen on the Incidence and Severity of Anthracnose (Colletotrichum gloeosporioides (Penzig) Penzig and Sacc.) of Onion. pp. 1-3

43. Yoldas, F.et al., 2011. Effect of Organic and Inorganic Fertilizers on Yield and Mineral content of Onion (Allium cepa L.African Journal of Biotechnology Vol. 10(55, pp. 11488-11492. http://www.academicjournals.org/AJB

44. Zibilske, Z. 2010. Soil Microbiology and Organic Matter in Crop Production USDA-ARS. http://www.dirtdoctor.com/soilmicrobiology-and-Organic-Matter-in Crop-Production_vq2296.htm 
